\title{
Recruitment and colonization of colonial ascidians (Tunicata: Ascidiacea) on intertidal rocks in Northeastern Brazil
}

\author{
Petrônio Bezerra Gama ${ }^{1}$, Rosa M. V. Leonel², Malva I. M. Hernández ${ }^{2}$ \& Beatriz Mothes ${ }^{3}$
}

\author{
1. Programa de Pós-Graduação em Ciências Biológicas (Zoologia), Departamento de Sistemática e Ecologia, Centro de Ciências \\ Exatas e da Natureza, Universidade Federal da Paraíba, 58059-900 João Pessoa, PB, Brasil. (petroniobg@gmail.com) \\ 2. Departamento de Sistemática e Ecologia, UFPB. (rleonel@oi.com.br) \\ 3. Museu de Ciências Naturais, Fundação Zoobotânica do Rio Grande do Sul, Rua Dr. Salvador França, 1427, 90690-000 Porto Alegre, \\ RS, Brasil.
}

\begin{abstract}
Recruitment and colonization of colonial ascidians, starting on natural scraped substratum, was observed throughout one year, in quadrats marked on sea- and continental-rock faces in the sublittoral fringe of an exposed beach in the Northeast of Brazil. The species of the Didemnidae, Didemnum duplicatum Monniot, 1983, D. psammathodes Sluiter, 1895, and Polysyncraton amethysteum Van Name, 1902, and an unidentified species of Polycitoridae, Eudistoma sp. 1, were recruited. Presenting continuous recruitment of all species, the density of living and dead recruits and colonies was similar on both faces of the rocks. The highest rainfall during winter, affected significantly the recruits density of $D$. duplicatum and $D$. psammathodes. Different permanence periods were observed for colonies of each species. The longest permanence periods were assigned to the colonies of P. amethysteum and D. psammathodes, extending up to four and five months, respectively.
\end{abstract}

KEYWORDS. Ecology, rocky shore, Didemnidae, Paraíba State.

RESUMO. Recrutamento e colonização de ascídias coloniais (Tunicata: Ascidiacea) em rochas de entre-marés no nordeste do Brasil. A partir de substrato natural raspado, o recrutamento e a colonização de ascídias coloniais foi observado ao longo de um ano, em unidades amostrais delimitadas sobre as faces mar e continente de rochas situadas na franja do infralitoral de uma praia exposta no nordeste do Brasil. Foram recrutadas as espécies de Didemnidae, Didemnum duplicatum Monniot, 1983, D. psammathodes Sluiter, 1895 e Polysyncraton amethysteum Van Name, 1902 e uma espécie não-identificada de Polycitoridae, Eudistoma sp. 1. Apresentando recrutamento contínuo de todas as espécies, a densidade de colônias e de recrutas vivos e mortos foi similar nas duas faces das rochas. Durante o inverno, a densidade de recrutas de $D$. duplicatum e de D. psammathodes foi significativamente afetada pela intensa pluviosidade. As colônias de cada espécie apresentaram diferentes períodos de permanência sobre as rochas. Com duração de quatro e cinco meses, os maiores períodos de permanência foram assinalados para as colônias de P. amethysteum e D. psammathodes, respectivamente.

PALAVRAS-CHAVE. Ecologia, praia rochosa, Didemnidae, Estado da Paraíba.

Several abiotic (temperature, period of exposure to solar radiation, hydrodynamic alterations, rainfall, sediment, depth) and biotic factors (reproductive patterns and period, presence of conspecifics, larval phototaxis, predation, etc.) may act separately or jointly, from the stage of liberation of larvae up to their settlement, metamorphosis, and growth on substratum on ascidian biology (Millar, 1952, 1958; Rocha, 1991; OSMAN \& Whitlatch, 1995a, b; RinKeVich et al., 1998; ROCHA et al., 1999; ForWARD JR. et al., 2000; HADFIELD \& PAUL, 2001).

In areas with extreme seasonal variations, water temperature has been considered as the main factor acting markedly on the control of the reproductive period of ascidians. Except for species of the boreal region, where the majority of ascidians reproduces in short or moderately long periods in the summer (Millar, 1958), the ascidians of subtropical waters tend to show continuous reproductive periods, though gonadal activity are depressed during winter (RocHA, 1991; Rocha et al., 1999). In tropical waters with annual temperature variation of only $6^{\circ} \mathrm{C}$, Goodbody (1961) reported continuous reproductive periods in solitary and colonial ascidians, with peaks of larval settlement not associated to any specific environmental factor.

As the colonial ascidians are considered good competitors, dominant on hard substrata and rapid colonizers of artificial substrata (RochA, 1995; OREN \& BENAYAHU, 1998), their larvae require clear spaces for colonization, whose speed of growth may occur according to each species (RochA, 1991; OREN \& BenAYAHU, 1998). Although some ascidians species are able to induce the settlement and metamorphosis of larvae by urochordamine metabolite (HADFIELD \& PAUL, 2001), the presence of adult colonies may affect the settlement, by usurpation of the primary substratum (OSMan \& Whitlach, 1995a, b).

Recruitment and growth of ascidians have been particularly evaluated on artificial substrata (Goodbody, 1961, 1962; Rocha, 1991; Osman \& Whitlatch, 1995a; Oren \& Benayahu, 1998) or on natural ones (RINKEVICH et al., 1998; RochA et al., 1999), under conditions of continuous immersion. Although ascidians occur in the intertidal region usually attached to fixed substrata (RodRigues et al., 1998; GAMA et al., 2001), studies on their recruitment and colonization in such environment have not been reported in the literature.

Planktonic larvae of marine organisms, until reaching the adult stage, experience several critical stages during the phases of dispersal and larval settlement, recruitment, and formation of young 
(Menge, 1991). According to Menge (1991), the recruitment rates of sessile species may be due to several causes, including: adults with low production of larvae per unit of beach area, low larvae survival in the plankton, mortality during and after recruitment, and the loss of larvae affected by unfavourable currents, among others.

Despite being present in the sublittoral zone of the Cabo Branco beach on the coast of Paraíba State, Brazil, the majority of colonial ascidians species also occurs in the sublittoral fringe, occupying the same relative position on the base strip of the rocks (up to $50 \mathrm{~cm}$ height), together with different species of sponges and macroalgae (GAma et al., 2001). Showing a similar development to the one observed in the sublittoral zone, a total of seven colonial ascidian species occurs with different frequencies, on rocks of the intertidal zone: Didemnum duplicatum Monniot, 1983, D. psammathodes Sluiter, 1895, Polysyncraton amethysteum Van Name, 1902, Cystodites dellechiajei (Della Vale, 1877), Eudistoma sp. 1, Eudistoma sp. 2 (Polycitoridae) and Symplegma rubra Monniot, 1972 (Stylidae).

Although the ascidians occur on both rock faces, their biomasses are higher on the side facing the continent, where the rock temperature is lower and the water speed is higher than on the side facing the sea (GAMA et al., 2001).
The main goal of this study was to evaluate the recruitment dynamics and the colonization capacity of colonial ascidians on rocks of the sublittoral fringe of the Cabo Branco beach.

\section{MATERIAL AND METHODS}

The Cabo Branco beach is located in João Pessoa, Paraíba State, Northeast of Brazil (Fig. 1). To the south, this beach is outlined by a cliff, originating the Ponta of Cabo Branco (708'50”'S; $34^{\circ} 47^{\prime} 51^{\prime \prime} \mathrm{W}$ ), situated approximately $2 \mathrm{~km}$ to the North of Cabelo River (Fig. 1).

As an exposed beach, Cabo Branco is submitted to hydrodynamic forces with water speed of $5 \mathrm{~m} / \mathrm{sec}$ during high tide (GAma et al., 2001). During spring tide, tidal water rises up to $2.6 \mathrm{~m}$, covering the entire littoral zone with a semidiurnal periodicity. During the lowest syzygy tides the area is totally uncovered for approximately $3 \mathrm{~h}$.

The tropical climatic conditions of the region of the present study are typical of the Northeastern coast of Brazil, characterized by a dry season (from September to February) and a rainy season (from March to August), with minimum and maximum air temperature of 24 and $36^{\circ} \mathrm{C}$, respectively, annual pluviometric index higher than $1,250 \mathrm{~mm}$, and insolation of $0.39 \mathrm{cal} \mathrm{cm}^{-2}$ $\min ^{-1}$ (NIMER, 1977).

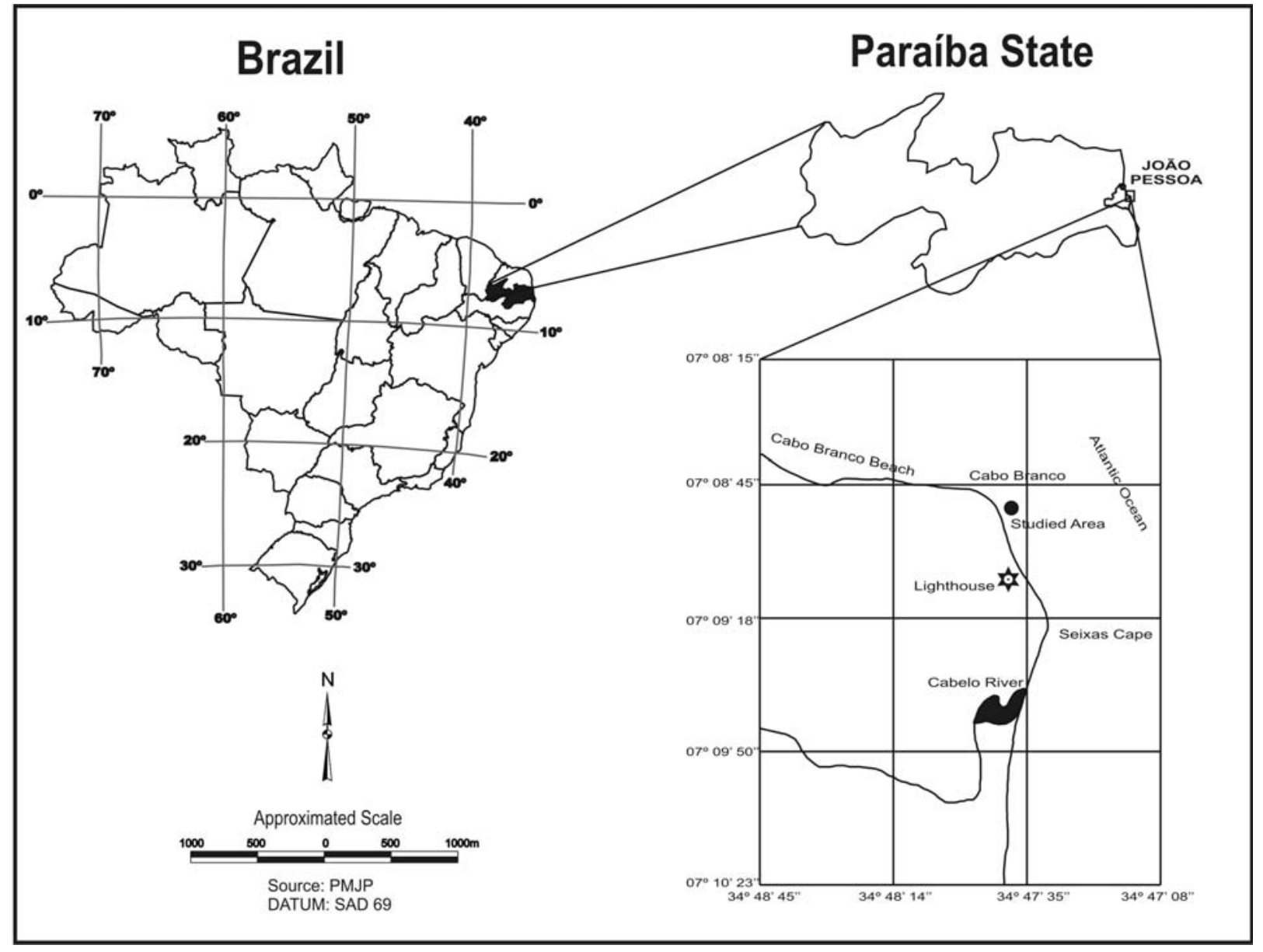

Fig. 1. Geographical localization of Cabo Branco in the coast of João Pessoa, Paraíba State and study area (๑). 
The present study was carried out on a group of four distinct rocks close to each other and located on the fringe of the sublittoral zone of the Ponta of Cabo Branco. Prior to the beginning of our observations, the organisms and their residues were removed completely from those rocks, by scraping them with a spatula and a steel brush, at a maximum height of 60 $\mathrm{cm}$ (depending on the rock height). In this way, our observations started from a bare substrate, with no subsequent scrapes. Considering the rock orientation relative to the sea and the continent, their faces were denominated as sea-face (SF) and continental-face (CF), respectively. For each rock, it was established the same quadrats number for each face, maintaining the same dimensions (width $\mathrm{x}$ height) of each quadrat/ face: (1) rock I, four quadrats with $26.0 \times 20.0 \mathrm{~cm}$ in CF and $28.0 \times 17.0 \mathrm{~cm}$ in SF; (2) rock II, three quadrats of $26.6 \times 25.0$ in $\mathrm{CF}$ and of $26.0 \times 17.0 \mathrm{~cm}$ in SF; (3) rock III, two quadrats of $43.0 \times 19.0 \mathrm{~cm}$ in $\mathrm{CF}$ and of $40.0 \times 17.0$ $\mathrm{cm}$ in SF; (4) rock IV, two quadrats of $46.0 \times 25.0 \mathrm{~cm}$ in $\mathrm{CF}$ and of $55.0 \times 22.0 \mathrm{~cm}$ in SF. With this experimental design, a total of 22 quadrats were offered as initial bare substratum, of which $8,009 \mathrm{~cm}^{2}$ in the continental face and $7,010 \mathrm{~cm}^{2}$ in the sea face.

Observations on the species recruitment and occurrence and permanence of ascidians colonies started one month after the scraping of the rocks and were carried out from July 2001 to June 2002. Every month, specific measures of the quadrats at each face were performed and plotted. At each quadrat, the recruits and colonies of each species were identified for their specific colour, texture and form. Their monthly occurrence and position were marked onto the quadrats and diagrammatically plotted. The areas occupied by colonies were drawn. Through the comparison of successive tabulations, the numbers of living and dead recruits and colonies were monthly evaluated on the two faces of each rock. After one month of recruitment, the absent specimen was considered as lost or dead recruit. The colonies were considered to be those specimens remaining on the rock for one or more months after the recruitment. Vanishing colony was interpreted as resulting from death or loss of specimen.

The monthly density of dead and living recruits and colonies was estimated. In order to observe a possible difference between the monthly mean density of recruits and the mean density of recruits present on both faces of the rocks, a two-way analysis of variance was performed, considering the values of density, i.e. number of individuals $/ \mathrm{m}^{2}$ obtained from each rock; Levene's test was previously applied to test the homoscedasticity of density data, which were square root transformed because of variance heterogeneity. Following this same procedure, the two-way analysis of variance was also applied to the density of dead recruits. The Pearson correlation was used to analyze the relation between the (1) pluviosity and density of living and dead recruits and (2) monthly mean density of number of recruits and of colonies. The software Statistica v. 4.0 for Windows was used for the statistical treatment (STATSOFT, 1998).

The percentage and the time of permanence of colonies of each species were calculated.

The superficial seawater temperature and salinity were determined monthly by using a mercury thermometer and a refractometer, respectively. The pluviometric data (three daily measurements) were obtained in the station of INMET $\left(07^{\circ} 05^{\prime} 34^{\prime \prime} \mathrm{S}\right.$; 3449'59'W), from the Laboratório de Meteorologia e Sensoriamento Remoto of the Universidade Federal de Campina Grande.

The ascidians, sponges and crabs species were deposited in the Paulo Young Marine Invertebrate Collection (CIMPY) of the Departamento de Sistemática e Ecologia, Centro de Ciências Exatas e da Natureza, Universidade Federal da Paraíba, João Pessoa, Brazil: Didemnum duplicatum (T. 05); D. psammathodes (T. 02); Polysyncraton amethysteum (T. 03); Eudistoma sp. 1 (T. 01); Cystodites dellechiajei (T. 06); Eudistoma sp. 2 (T. 11); Symplegma rubra (T.38); Tedania ignis (P. 01); Cliona sp. (P. 16); Haliclona sp (P. 26); Halichondria sp. (P. 29); Ircinia sp. (P. 15); Eriphia gonagra (4926) (4927) (4928) (4929); Cryptodromiopsis antillensis (5062) (5063).

\section{RESULTS}

During the first month of observation, a predominant attachment of the algae Gelidium sp. and Cladophora sp., in several strips of the scraped substratum, occurred on all sampled rocks. In the subsequent months, a large reduction and a further disappearance of those plants occurred, except Gelidium sp. that remained at scattered bunches on the rocks. From July 2001 the recruitment of the ascidians D. psammathodes, D. duplicatum, Eudistoma sp. 1, and $P$. amethysteum began, and in a smaller amount, the sponges Tedania ignis (Duchassaing \& Michelotti, 1867), Cliona sp., Haliclona sp., Halichondria sp., and Ircinia sp. Despite being present on other rocks on the beach, the ascidians C. dellechiajei, S. rubra, and Eudistoma sp. 2 were not recruited. Although the sponges Cliona sp. and Haliclona sp. had been sporadically recruited on colonies of D. psammathodes, the attachment of ascidians recruits on colonies was rarely noted.

The total loss of recruits was high, between $42.1 \%$ and $71.4 \%$, depending on the species (Tab. I).

For all the species the ANOVA made clear that the densities of recruits and dead individuals were similar on both faces of the rocks (Tab. II).

The analysis of the variation of the monthly mean density of recruits showed significant differences throughout the year for all the species $(D$. psammathodes: $\mathrm{F}_{(11.72)}=2.15 ; \mathrm{p}<0.05 ; D$. duplicatum: $\mathrm{F}_{(1172)}=4.71 ; \mathrm{p}<0.05 ;$ Eudistoma sp. $1: \mathrm{F}_{(11.72)}=3.15$; $\mathrm{p}<0.05$; and P. amethysteum: $\left.\mathrm{F}_{(11.72)}=5.66 ; \mathrm{p}<0.05\right)$ not resulting in defined decrease or increase pattern of density of recruits in relation to time elapsed (Figs. 2$5)$.

With respect to monthly mean density of dead recruits, the results from ANOVA emphasized significant differences throughout the year for the species: D. psammathodes $\left(\mathrm{F}_{(11.72)}=4.79 ; \mathrm{p}<0.05\right), D$. 
duplicatum $\left(\mathrm{F}_{(1172)}=6.96 ; \mathrm{p}<0.05\right)$ and P. amethysteum $\left(\mathrm{F}_{(11.72)}=5.19 ; \mathrm{p}<0.05\right)$ (Figs. 2-4). No significant difference was obtained for density of dead recruits of Eudistoma sp.1 $\left(\mathrm{F}_{(11.72)}=1.58 ; \mathrm{p}=0.12\right)$ throughout the year (Fig. 5).

Finally, the two-way analyses of variance showed no statistical interaction $(p>0.05)$ of density of recruits
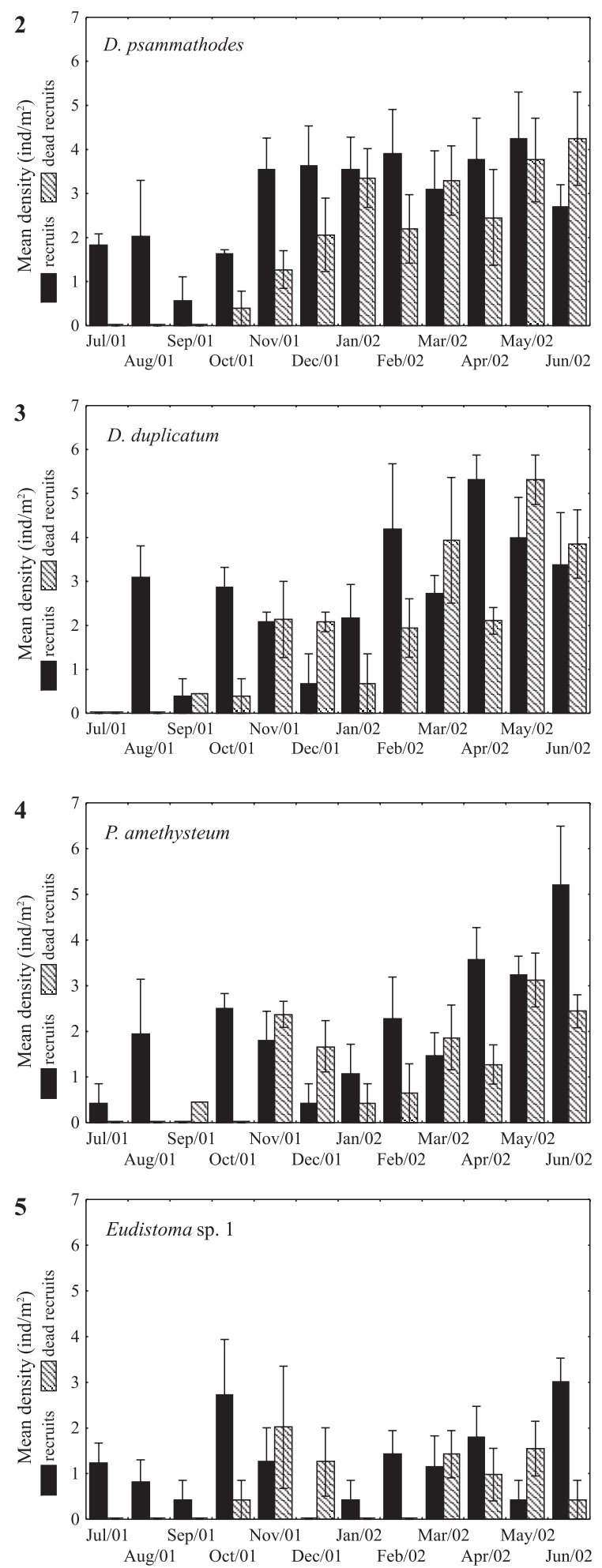

between the faces of the rocks and month of observation, clearly demonstrating that the presence and loss of recruits on both faces of the rocks were not related to the months of the present study.

No correlation was obtained between mean densities of recruits and of colonies of each species.
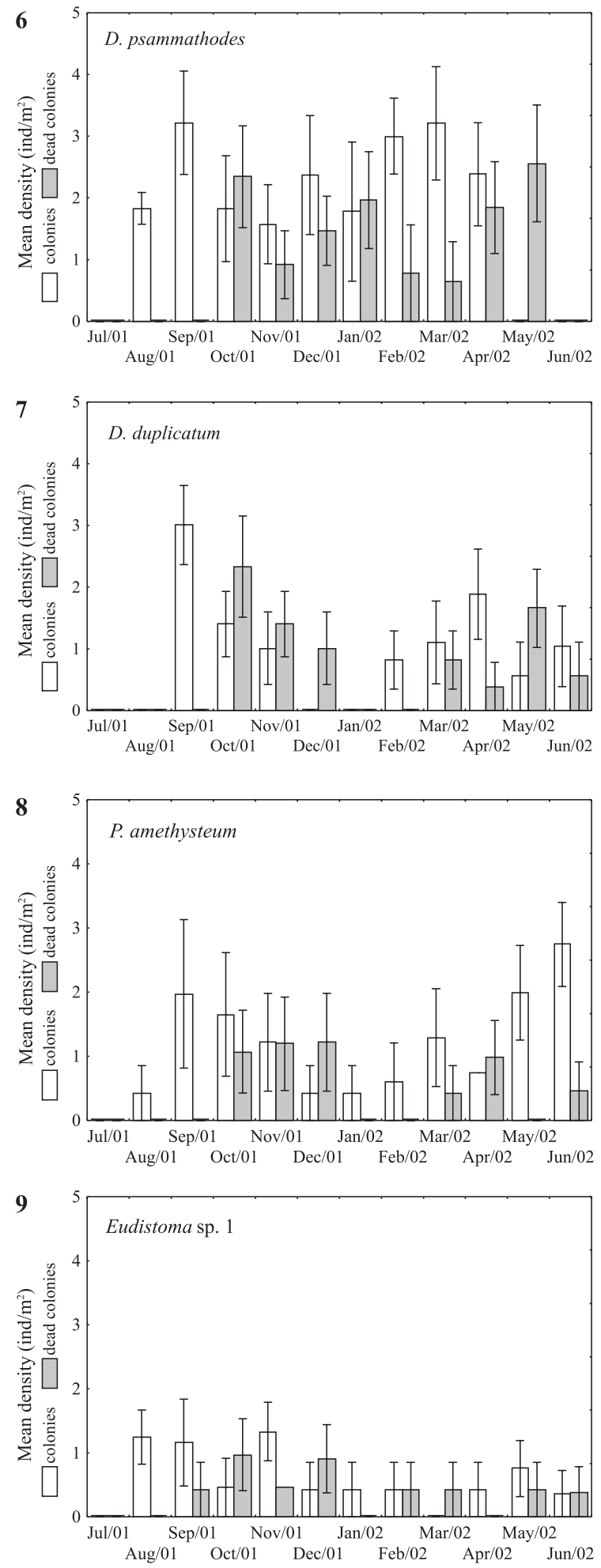

Figs. 2 - 9. Mean density of living and dead recruits, and colonies of the ascidians, in Cabo Branco beach, from July 2001 to June 2002 , respectively: 2,6, Didemnum psammathodes; 3,7, Didemnum duplicatum; 4,8, Polysyncraton amethysteum; 5,9, Eudistoma sp. 1. 
Table I. Monthly and total number of recruited individuals and dead recruits, and the percentage of dead recruits of Didemnum duplicatum, D. psammathodes, Polysyncraton amethysteum, and Eudistoma sp. 1, on rocks of the sublittoral fringe; water temperature, salinity, and pluviometric index in Cabo Branco beach, João Pessoa, Paraíba State, from July 2001 to June 2002.

\begin{tabular}{|c|c|c|c|c|c|c|c|c|c|c|c|c|c|c|}
\hline \multirow[t]{2}{*}{ Species } & \multicolumn{6}{|c|}{2001} & \multicolumn{6}{|c|}{2002} & \multirow{2}{*}{ Total } & \multirow{2}{*}{$\begin{array}{c}\text { Dead } \\
\text { Recruits } \\
(\%)\end{array}$} \\
\hline & Jul & Aug & Sep & Oct & Nov & Dec & Jan & Feb & Mar & Apr & May & Jun & & \\
\hline \multicolumn{15}{|l|}{ Didemnum psammathodes } \\
\hline Recruits & 2 & 14 & 2 & 4 & 20 & 25 & 20 & 27 & 18 & 26 & 30 & 12 & 200 & - \\
\hline Dead & 0 & 0 & 0 & 0 & 3 & 9 & 19 & 9 & 18 & 15 & 26 & 30 & 129 & 71.4 \\
\hline \multicolumn{15}{|l|}{ Didemnum duplicatum } \\
\hline Recruits & 0 & 16 & 1 & 13 & 7 & 3 & 9 & 34 & 12 & 44 & 28 & 22 & 189 & - \\
\hline Dead & 0 & 0 & 1 & 1 & 10 & 7 & 3 & 7 & 30 & 7 & 44 & 25 & 135 & 63.5 \\
\hline \multicolumn{15}{|l|}{ Polysyncraton amethysteum } \\
\hline Recruits & 1 & 10 & 0 & 10 & 7 & 1 & 3 & 11 & 4 & 20 & 16 & 43 & 126 & - \\
\hline Dead & 0 & 0 & 1 & 0 & 9 & 6 & 1 & 2 & 7 & 3 & 15 & 9 & 53 & 42.1 \\
\hline Eudistoma sp. 1 & 3 & 2 & 1 & 19 & 5 & 0 & 1 & 4 & 4 & 8 & 1 & 15 & 63 & - \\
\hline Dead & 0 & 0 & 0 & 1 & 15 & 5 & 0 & 0 & 4 & 3 & 6 & 1 & 35 & 55.5 \\
\hline Water Temperature $\left({ }^{\circ} \mathrm{C}\right)$ & 29 & 28 & 33 & 32 & 33 & 29 & 32 & 31 & 32 & 32 & 29 & 29 & & \\
\hline Salinity (psu) & 35 & 35 & 35 & 37 & 37 & 36 & 37 & 36 & 37 & 37 & 35 & 37 & & \\
\hline Pluviometric index $(\mathrm{mm})$ & 185 & 62 & 43 & 22 & 16 & 40 & 179 & 143 & 251 & 190 & 255 & 471 & & \\
\hline
\end{tabular}

Table II. Mean density of living and dead recruits of species of ascidians on the sea (SF) and continent-faces (CF) of the rocks, and the analysis of variance, in Cabo Branco beach, João Pessoa, Paraíba State, from July 2001 to June 2002 (F, Fisher value; p, probability).

\begin{tabular}{lccc}
\hline & SF & CF & ANOVA \\
\hline Living recruits & & & \\
Didemnum psammathodes & 2.86 & 2.23 & $\mathrm{~F}_{(1.72)}=1.93 ; \mathrm{p}=0.17$ \\
Didemnum duplicatum & 2.56 & 2.09 & $\mathrm{~F}_{(1.72)}=1.32 ; \mathrm{p}=0.25$ \\
Polysyncraton amethysteum & 1.99 & 1.61 & $\mathrm{~F}_{(1.72)}=1.22 ; \mathrm{p}=0.27$ \\
Eudistoma sp. 1 & 1.11 & 0.97 & $\mathrm{~F}_{(1.72)}=0.22 ; \mathrm{p}=0.64$ \\
Dead recruits & & & \\
Didemnum psammathodes & 1.93 & 1.46 & $\mathrm{~F}_{(1.72)}=1.53 ; \mathrm{p}=0.22$ \\
Didemnum duplicatum & 1.77 & 1.59 & $\mathrm{~F}_{(1.72)}=0.24 ; \mathrm{p}=0.63$ \\
Polysyncraton amethysteum & 1.10 & 0.93 & $\mathrm{~F}_{(1.72)}=0.49 ; \mathrm{p}=0.48$ \\
Eudistoma sp. 1 & 0.54 & 0.49 & $\mathrm{~F}_{(1.72)}=0.03 ; \mathrm{p}=0.87$ \\
\hline
\end{tabular}

The water temperature and salinity remained high, with no noticeable seasonal variation. The highest rainfall values were recorded in July 2001 and between March and June 2002, and the lowest values were recorded between August and December 2001 (Tab. I). Rainfall correlated positively and significantly to density of recruits of $P$. amethysteum ( $\mathrm{r}=0.64 ; \mathrm{p}<0.05)$. Rainfall also correlated positively and significantly $(\mathrm{p}<0.05)$ to density of dead recruits of $D$. psammathodes $(\mathrm{r}=0.73)$ and of $D$. duplicatum $(\mathrm{r}=0.61)$.

The mean density of live and dead colonies (Figs. 6-9) did not show any seasonal pattern. The largest population densities of colonies were registered among Didiminidae, with predominance of $D$. psammathodes.

The permanence of colonies varied from one to five months (Tab. III). Colonies of $P$. amethysteum and $D$. psammathodes had the longest permanence, from four to five months, respectively. Colonies of $D$. duplicatum had the shortest permanence (two months). The ascidians D. psammathodes and Eudistoma sp. 1 presented the largest and the smallest number of colonies, respectively. One-month life colonies were the most numerous. A decrease in the number of colonies usually occurred the longer the permanence was. Colonies of different ages occurred simultaneously.

\section{DISCUSSION}

The low number of recruited specimens and the loss or death of a large number of recruits and colonies, reflect the difficulties of ascidians to colonize rocky substrata under the local abiotic conditions at the intertidal zone of the study area. Although the larval settlement of some ascidians species occurs close to the parental colony (OSMAN \& WhitLATCH, 1995a; YUND \& STIRES, 2002), under intertidal conditions, many larvae may disperse for longer distances since a rapid settlement does not occur (FORWARD JR. et al., 2000). Besides the influence of wind and temperature during air exposure periods, the effect of waves and the high speed of water flow in the area may be considered as likely factors that interfere on dispersion and larval settlement, on survival and permanence of recruits and colonies on the rock. On the other hand, as predicted by Menge (1991), the data here obtained may reflect the low production of larvae per unit of beach as well as the low rate of larvae survival up to recruit and juvenile stages.

In the occupation of substratum, predominance of recruits and colonies of species of Didemnidae has occurred, confirming the trend observed for other species of this same family on submerse substrata (RocHA, 1991). The observed fact of all species being recruited from bare substratum showed clearly that at least in the first month of recruitment, the larval settlement was independent of the parental influence on the studied rocks, but dependent of colonies in reproductive activity in the adjacent rocks.

Despite the absence of correlation between colonies and recruits, which seems to confirm such evidence throughout the period of the experiment, this result may have been influenced by the loss of recruits and colonies in the intervals of observations. Nonetheless, it is still necessary to make clear if through time, the resident colonies contributed to the production and recruitment of larvae.

The almost total absence of recruits on colonies indicates that the larvae of ascidians at Cabo Branco may present the same ability of discriminating the substratum 
Table III. Permanence, absolute amount (monthly and total) and annual percentage of ascidians colonies of Didemnum duplicatum, D. psammathodes, Polysyncraton amethysteum, and Eudistoma sp. 1, from July 2001 to June 2002 on four rocks of the infralittoral fringe, in Cabo Branco beach, João Pessoa, Paraíba State. The black and grey bars indicate the lifetime of colonies, starting from the first month of recruitment.

\begin{tabular}{|c|c|c|c|c|c|c|c|c|c|c|c|c|c|c|}
\hline \multirow[t]{2}{*}{ Species } & \multirow{2}{*}{$\begin{array}{l}\text { Settlement } \\
\text { time }\end{array}$} & \multicolumn{6}{|c|}{2001} & \multicolumn{5}{|c|}{2002} & \multirow[t]{2}{*}{ Total } & \multirow[t]{2}{*}{$\%$} \\
\hline & & Jul & Aug & Sep & Oct & Nov & Dec & Jan & Feb & Mar & Apr & May Jun & & \\
\hline \multirow{4}{*}{$\begin{array}{l}\text { Didemnum } \\
\text { duplicatum }\end{array}$} & 1 month & & & 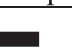 & & 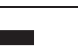 & & & & & 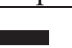 & & & \\
\hline & $\mathrm{N}$ & & 15 & & 3 & & & 2 & & 4 & 5 & 4 & 33 & 78.6 \\
\hline & 2 months & & & 4 & & & & & 3 & & & & 9 & 21.4 \\
\hline & & & & 4 & & & & & & & 2 & & & \\
\hline \multirow{12}{*}{$\begin{array}{l}\text { Didemnum } \\
\text { psammathodes }\end{array}$} & 1 month & & & & & & & & & & & & & \\
\hline & $\mathrm{N}$ & & 12 & & & 10 & 3 & 4 & 3 & & 3 & & 35 & 56.4 \\
\hline & 2 months & - & & & & & & & & 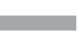 & & & & \\
\hline & $\mathrm{N}$ & & 3 & & & & 1 & & 3 & & & & 13 & 21.0 \\
\hline & & & & 1 & & & & & & 5 & & & & \\
\hline & 3 months & 1 & & & & & 1 & & & & & & & \\
\hline & $\mathrm{N}$ & 1 & & 4 & & & & & 3 & & & & 9 & 14.5 \\
\hline & 4 months & & & & & & & & & & & & & \\
\hline & $\mathrm{N}$ & 1 & & & & & $\boldsymbol{\square}$ & 1 & & & & & 4 & 6.4 \\
\hline & 5 months & & & 1 & & & & 1 & & & & & & \\
\hline & $\mathrm{N}$ & & & & & & & & & & & & 1 & 1.6 \\
\hline & & & & & & & & 1 & & & & & & \\
\hline \multirow{8}{*}{$\begin{array}{l}\text { Polysyncraton } \\
\text { amethysteum }\end{array}$} & 1 month & & 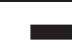 & & 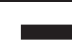 & & & - & & & & C & & \\
\hline & $\mathrm{N}$ & & 4 & & 1 & & & 1 & 2 & 1 & 2 & 7 & 18 & 52.9 \\
\hline & 2 months & & & & & & & & & & & & & \\
\hline & $\mathrm{N}$ & 1 & & 5 & ש & & & & & & & 4 & 10 & 29.4 \\
\hline & 3 months & & & & & & & & & & & & & \\
\hline & $\mathrm{N}$ & & & & 3 & & & & & & & & 3 & 8.8 \\
\hline & 4 months & & & & & & & & & & ? & & & \\
\hline & $\mathrm{N}$ & & & & & & 1 & & & & 2 & & 3 & 8.8 \\
\hline \multirow[t]{6}{*}{ Eudistoma sp. 1} & 1 month & & & & & & & & & & & & & \\
\hline & $\mathrm{N}$ & 1 & 1 & & & 3 & & 1 & & & 1 & 1 & 8 & 72.7 \\
\hline & 2 months & - & & E & & & & & & & & & & \\
\hline & $\mathrm{N}$ & 2 & & 1 & & & & & & & & 1 & 4 & 18.2 \\
\hline & 3 months & & & & & & & 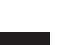 & & & & & & \\
\hline & $\mathrm{N}$ & & & & & 1 & & & & & & & 1 & 9.1 \\
\hline
\end{tabular}

as reported by Osman \& Whitlatch (1995b) for Diplosoma macdonaldi Herdman, 1886 and Botrylloides diegensis (Ritter \& Forsyth, 1917).

Despite differences on hydrodynamics and temperature on the rocks surface between the sea-face and the continental-face recorded in the study area, no difference was observed between the density of recruits and of colonies on both faces. However, as the abrasive action and pressure of waves on a rocky beach may tear and rip organisms from the rock (LEVINTON, 1995), this may have been one of the most relevant factors on the transitory permanence of juvenile recruits and colonies, especially during the first month of life. By reflecting the population dynamics of colonies, these results project and confirm the same pattern of occurrence on both rock faces reported by GAMA et al. (2001) for colonies present in the mesolitoral.

As suggested by GoodBody (1961), considering that the presence of recruits represents the period of larvae release, our results show the existence of a continuous reproductive period for all species. In the absence of information on reproduction of the ascidians we studied, 
the results of recruitment indicate a likely specific variation of the amount of larvae produced.

The high water temperature, varying only $5^{\circ} \mathrm{C}$ throughout the year may have been one of the most strikingly factors favourable to a continual production of larvae, confirming similar results reported by GoODBODY (1961) for ascidians of Jamaica.

The monthly evaluation of the salinity indicates a variation of only 5 psu. The influence of River Cabelo on the salinity in the study area should not be considered because of its low water flow. However, pluviometric data indicate that a larger dilution of the superficial salinity might have occurred. As during the period of rains also occurs increase of the amount of sediment in the water, we can infer that the direct action of the rain, the dilution of the water and the presence of larger amount of sediment in the water, might have caused the mortality of the recruits of $D$. psammathodes and $D$. duplicatum. Data of the literature confirm high mortality of young specimens under intense rains (GoOdBODY, 1961), and indicate ascidians susceptibility to certain amounts of suspended particulate matter in the water (RODRIGUES et al., 1998).

As reported by Rocha (1991), competitive interactions between adults were never observed, always existing available spaces to the occupation of the quadrats. Therefore, the competition for space and the inter-specific competition cannot be understood as a limiting factor to the permanence of the colonies on the rocks. However, the permanence of colonies on substratum may be associated to the influence of abiotic conditions and to the peculiarities of each species, concerning the form, incrustation type, lifetime, and tolerance to environmental variations. Colonies of $D$. psammathodes and P. amethysteum, with $c a$. of 1.0 to 3.0 mm thick (RoDRIGUES et al., 1998), grow overlapping and firmly attached to the substratum, whereas Eudistoma sp. 1 forms massive colonies, prominently and more weakly attached to the rocks. In this way, under the abrasive action of the waves, the characteristics of Eudistoma sp. 1 may favour a larger loss of their colonies, especially in the initial stages of their development, when the surface: volume ratio is higher. As a consequence of such characteristics, larger number and longer time of permanence of $D$. psammathodes colonies are a possible explanation to a greater frequency of occurrence of this species on rocks of the intertidal zone.

Although the predation of recruits and colonies has not been investigated in the present work, the action of predators might have interfered in the permanence of those organisms on the rocks. Field observations enable us to report the predatory action of the crab Eriphia gonagra (Fabricius, 1781) on D. psammathodes, and the behaviour of the crab Cryptodromiopsis antillensis (Stimpson, 1858), which as a whole of its body surface is covered with entire colonies of Eudistoma sp. 1.

The data here obtained indicate that, under the intertidal conditions of Cabo Branco beach, the great loss of recruits and the short permanence of the colonies result in a slow process of colonization of the rocky substratum for compound ascidians.
Acknowledgements. We are grateful to Drs Rosana M. Rocha and Tatiane Regina Moreno, Universidade Federal do Paraná, and to Dr. Gustavo S. Melo, Museu de Zoologia da Universidade de São Paulo, for the previous identification of species of ascidians and crabs, respectively; to Dr. Breno Grisi, for reviewing the manuscript and its translation into English; to the Laboratório de Meteorologia e Sensoriamento Remoto of the Universidade Federal de Campina Grande, for the pluviometric data; to the geographer Utaiguara de Nóbrega Borges for the elaboration of the map; to CAPES, for scholarship granted to P. B. Gama, and to CNPq, for a 'DCR' grant to M. I. M. Hernández.

\section{REFERENCES}

Forward, R. B., Jr.; Welch, J. M. \& Young, C. M. 2000. Light induced larval release of a colonial ascidian. Journal of Experimental Marine Biology and Ecology 248:225238

Gama, P. B.; Leonel, R. M. V. \& Miranda, G. E. C. 2001. Estudo estacional de comunidade de substrato duro da região de entremarés da Ponta do Cabo Branco, João Pessoa, Paraíba. In: SouzA, M. F. V. ed. Iniciados. João Pessoa, Editora Universitária. v. 8, p.64-84.

Goodbody, I. 1961. Continuous breeding in three species of tropical ascidian. Proceedings of the Zoological Society of London 136:403-409.

- 1962. The biology of Ascidia nigra (Savigny). I. Survival and mortality in an adult population. Biological Bulletin 12:40-51

Hadfield, M. G. \& Paul, V. J. 2001. Natural chemical cues for settlement and metamorphosis of marine-invertebrate larvae. In: Mc Clintok, J. B. \& Baker, J. B. eds. Marine Chemical Ecology. Boca Raton, CRC. p.431-461.

Levinton, J. S. 1995. Marine Biology - function, biodiversity, ecology. New York, Oxford University. $420 \mathrm{p}$.

Menge, B. A. 1991. Relative importance of recruitment and other causes of variation in rocky intertidal community structure. Journal of Experimental Marine Biology and Ecology 146:69-100.

MillaR, R. H. 1952. The annual growth and reproductive cycle in four ascidians. Journal of the Marine Biological Association of the United Kingdom 31:41-61.

1958. The breeding season of some littoral ascidians in Scottish waters. Journal of the Marine Biological Association of the United Kingdom 37:649-652.

Nimer, E. 1977. Clima. In: Goldemberg, C. ed. Geografia do Brasil. Região Nordeste. Rio de Janeiro, Sergraf-IBGE. v.2, p.47-84.

Oren, U. \& Benayahu, Y. 1998. Didemnid ascidians: rapid colonizers of artificial reefs in Eilat (Red Sea). Bulletin of Marine Science 63(1):199-206.

Osman, R. \& Whitlatch, R. B. 1995a. The influence of resident adults on recruitment: a comparison to settlement. Journal of Experimental Marine Biology and Ecology, 190:169198 .

1995b. The influence of resident adults on larval settlement: experiments with four species of ascidians. Journal of Experimental Marine Biology and Ecology 190: 199-220.

Rinkevich, B.; Porat, R. \& Goren, M. 1998. Ecological and life history characteristics of Botryllus schlosseri (Tunicata) populations inhabiting undersurface shallow-water stones. Marine Ecology 19(2):129-145.

RochA, R. M. 1991. Replacement of the compound ascidian species in a southeastern Brazilian fouling community. Boletim do Instituto Oceanográfico 39(2):141-153. 1995. Abundance and distribuition of sessile invertebrates under intertidal boulders (São Paulo, Brazil). Boletim do Instituto Oceanográfico 43(1):71-88.

Rocha, R. M.; Lotufo, T. M. C. \& Rodrigues, S. A. 1999. The biology of Phallusia nigra Savigny, 1816 (Tunicata: Ascidiacea) in southern Brazil: spatial distribution and 
reproductive cycle. Bulletin of Marine Science 64(1):77-87

Rodrigues, S. A.; Rocha, R. M. \& Lotufo, T. M. C. 1998. Guia ilustrado para identificação das ascídias do Estado de São Paulo. São Paulo, Parma. 190p.
StatSoft, Inc. 1998. Statistica for Windows (Computer Program Manual). Tulsa, StatSoft, Inc.

Yund, P. O. \& Stires, A. 2002. Spatial variation in population dynamics in a colonial ascidian (Botryllus schlosseri). Marine Biology 141:955-963.

Recebido em junho de 2005. Aceito em março de 2006. ISSN 0073-4721

Artigo disponível em: www.scielo.br/isz 